\section{Dr.Racha EI Moslemany}

Accounting and Finance Department Arab Academy for Science, Technology and Maritime Transport, Egypt

Dr. Demyana Nathan

Accounting and Finance Department Arab Academy for Science, Technology and Maritime Transport, Egypt

\section{The Effect of Ownership Struc- ture on Firm's Financial Per- formance: An Empirical Study on companies listed on the Egyp- tian Stock Exchange}

\section{Abstract}

This paper examines the relationship between firms' ownership structure and financial performance as measured by Return on assets (ROA), return on equity (ROE) and Tobin's Q in Egypt, using a sample of fifty listed companies between 2003 and 2015. The main dimensions of the ownership structure are: Managerial Ownership, Government Ownership and Block Holders. Data was extracted from the annual reports of these companies and from available information on their websites. The study used regression as a tool of analysis.The results confirm a positive relationship between managerial and government ownership structure and financial performance. However, an insignificant relationship was found between government ownership and the firm performance of the firms under study.

\section{Key words}

Corporate Governance, Financial Performance, Ownership Structure, Managerial Ownership, government Ownership and Block Holders.

\section{Introduction}

The concept of corporate governance was discussed in details in previous literature. of the important issues discussed is Ownership structure. Ownership structure is considered a subject of corporate governance. Corporate governance system is needed for any company's growth and development (Fazlzadeh et al., 2011). Corporate governance protects the welfare of individual and all the stakeholders which facilitate the creation of their value through management of the corporate governance (Hasan and Butt, 2009). A good corporate governance system leads to gaining trust of investors and lenders. Corporate governance sometimes results in the existence of agency problem and its origin can be related to the separation between the ownership and the control of any organization(Goyal and Park, 2002; Ballinger and Marcel, 2010. Agency problems rise from the conflict of interest between shareholders and managers within the firm.(Fazlzadeh et al., 2011).

Corporate governance structure determines how rights and responsibilities are distributed between the different stakeholders in a business enterprise. Corporate governance mechanisms are expected to affect achievement of corporate objectives at a minimal cost. This 
is because the means of monitoring performances will be provided resulting in strengthened protection of interest and confidence of investors. Part of the internal corporate governance mechanisms is ownership structure. In this study, ownership structure is assumed to be managerial, government, and block holders' ownership (Goyal and Park, 2002; Ballinger and Marcel, 2010).The relation between ownership structure and firm performance has been of a great importance in the literature starting from Berle and Means (1932). These researchers argued that a dispersed ownership structure leads to low financial performance.According to them, the concentration of ownership would lead to good firm financial performance. Several studies were performed to discuss the link between the ownership structure and financial performance, but most of these studies were conducted in the developed countries. The developing economies, particularly from the African continent have limited studies conducted so far (Adebiyi and Sunday, 2011; Andow and David, 2016; TaufilMohd et al., 2013; Gunasekarage et al., 2007; Mishra and Phung, 2015; Hess et al., 2010; Ng et al., 2009).

Each type of ownership structures influences the firm performance in a different way. The ownership structure plays an important role in determines a firm ultimate success. Nevertheless, the same issue goes to firms' corporate governance practice. Derived from previous studies, ownership structure and corporate governance practice are not standardizing across different economic situation as there are differences in areas such as corporate law and investor protection (Ugurlu, 2000; Shakir, 2008) . In other words, the effects of owner- ship structures and corporate governance may attributed to countries specific conditions, such as domestic culture, national tax motivations, and differences in national legal structures. In sum, each economic sector would have a different type of suitable ownership structure and corporate governance practice that enhance the performance of the fi$\mathrm{rm}$. If the firm fails to establish a viable ownership structure and corporate governance, this might lead to results that are unexpected by the shareholders. This discussion point that ownership structure and corporate governance are important factors in improving firm performance (Elvin and Abdul Hamid, 2016). One of the main features of the ownership structure in Egypt involves considerable controlling stakes of some families, financial and industrial institutions, and the government. Egyptian companies have one tier boards comprised of an odd number of members, with a minimum of three. The board of directors of a joint stock company should include a more non-executive members than executive members with an appropriate mix of ski1ls, technical, or analytical experience (Abdelsalam et al., 2008).

This study provides additional evidence regarding the way in which ownership structure influences Company's performance in Egypt focusing on the conflict emanating on incentives due to managerial, government and block holders' ownership participation on Corporate Governance structure and their impact on the firm's performance. Most of the studies perceive that ownership concentration is positively related to the financial performance, as with a large 
controlling shareholder, the company's monitoring costs will decrease. There is also an assumption that managers are imperfect agents of shareholders, as they could attempt to pursue their own goals rather than work on improving the shareholders' wealth. This is the reason why many families tend to entrust their business operations to family members who are also co-owners. Performance is crucial to any business organisation survival and continues patronage by investors, potential investors, potential investors, creditors, and other stakeholders in the business world. Every firm takes important decision in order to make returns. This decision is important since the survival of the firm is related to its ability to make profits. Moreover, ownership structure of any company has been a serious agenda for corporate governance and that of firm's performance (Andow and David, 2016).

\section{Literature Review and the- Hypothesis}

Since the relationship between ownership structure and firm performance depends mainly on corporate governance, corporate governance explains the relationship between firms and its shareholders.This is a known as Agency theory. Widespread opinions view corporate governance as a complex affair that describe not only the relationship between the firm and its owners but also the relationship with the large number of stakeholders like customers, sellers, employees, and more. This theory is known as the Stakeholders theory (Goyal and Park, 2002; Ballinger and
Marcel, 2010). The most convenient definition for the corporate governance is as follows: "Procedures and processes according to which an organization is directed and controlled". According to the literature, some other mechanisms are also proposed to explain the relationship between ownership structure and firm performance beside agency cost approach. In general, agency theory is used to examine the relationship between leaders and agents but the need to understand the conflict between the different classes of leaders' increases, as some owners might have different strategies to monitor. Since there is a conflict between managers and owners that causes agency costs, the agency problem has been discussed widely in the ownership structure literature (Fazlzadeh et al., 2011).

\section{Managerial Ownership and firm financial performance}

The Agency theory states that managers have different goals and objectives that might contradict with those of the stakeholders. Since managers are assumed to favor their own goals on the expense of shareholders welfare, managers are likely to take decisions that may hurt their shareholders (Fazlzadeh et al., 2011). Some studies argued that greater equity ownership by insiders (management and/ or directors) improves corporate performance because it aligns the monetary incentives of the manager with other shareholders, thereby mitigating the standard principal-agency problem (Adebiyi and Sunday, 2011; Andow and David, 201).The relation between managerial ownership and the performance of the firm was identified. The conflict of interest hypothesis explains the positive relationship of man- 
agerial ownership and the firm performance. This means that, with a reasonable high level of managerial ownership, the performance will be better (Andow and David, 2016). Higher board ownership improves firm performance because it better aligns the incentives of managers with other shareholders, thereby reducing agency problems between managers and owners. Ownership by managers and board members provides an incentive to ensure that the firm is managed properly as their wealth are being tied up to the firms performance (Taufil-Mohd et al., 2013). In a study, the relation between managerial ownership and the firm performance was examined. Using the data of 648 German firms between the years 2003 and 1998, it was found that there is a positive and significant relationship between corporate performance as measured by return on assets and managerial ownership (Kaserer and Moldenhauer, 2008).

In another study, the effect of board structure on corporate financial performance in Nigeria was examined. This study identified four variables including board composition, board size, board ownership and CEO duality. The results of this study detected a strong positive relation between board size and corporate financial performance. On the other hand, they found a negative relation between directors' stockholding and firm financial performance as measured by ROE (Uadiale,2010). The firm will have a lower value when managers with a high level ownership also have enough voting power to ensure their position inside the firm (Andow and David, 2016).
However, other studies argued that the effect of managerial ownership on firm performance would change with the degree of ownership. At low and high level of ownership, firm performance decrease, but performance increases at intermediate level.Therefore, the effect of managerial ownership on firm performance is a double-edged sword (Zakaria and Purhanudin, 2014).

\section{The first hypothesis is as follows: \\ H1:There is a relationship between Managerial ownership and firm performance.}

\section{Block holders Ownership and firm financial performance}

Block holders, in the form of foreigners and domestic private institutional investors, could play an effective monitoring role. Given that many firms are controlled by families, the existence of block holders could reduce the agency problems between majority and minority shareholders. By controlling a significant amount of ownership, block holders have an incentive to monitor the firm performance as their wealth is tied up to the firm performance. Furthermore, institutional investors, looking for profitable investment opportunities would only invest in firms with expected better future performance (Taufil-Mohd et al., 2013).

Institutional investors also can be effective monitors, because institutional investors have the means and power to properly monitor and affect management decisions. It is claimed that firm performance increase as institutional ownership grows (Lee, 2008). Furthermore, institutional investors, looking for profitable investment opportunities wo- 
uld only invest in firms with expected better future performance (Taufil-Mohd et al., 2013).

In the market economy, the ownership is separated from the control. Companies are managed by the professional managerial team. However, the widespread ownership of listed companies causes the collective supervision infeasible (Hart, 1995). At the same time, the widespread ownership structure generates the problem of free riders. Individual and small shareholders who either lack interest or the abilities to monitor companies, or both (Hansmann and Kraakman, 2004). Thus, they prefer to rely on other shareholders to monitor the management. Ownership by institutional investors is mainly through portfolio investments. Institutional investors tend to have low risk aversion and relatively long investment horizon, yet their performance is usually measured by the financial success of their investments (Zhang and Kyaw, 2017).

As discussed before, block holders investors also can be important owners, because they have the means and power to monitor and control management's decisions. It is assumed that there is a positive effect of block holders' ownership on the performance of the firm. However, although block holders owners have positive effect on firm performance, it seems that when they own a large block of share of a company, the managers of these firms would be affected by the large shareholder's power and hence, they would try to satisfy them. This may finally have a negative effect on firm performance (Fazlzadeh et al., 2011).
Thus, the second hypothesis is as follows:

H2:There is a relationship between block holders ownership and firm performance.

\section{Government Ownership and} firm financial performance

Government ownership and the firm performance have a curved relationship (Wei and Varela, 2003; Wei et al., 2005 ; $\mathrm{Ng}$ et al., 2009). The privatization of firm along with government control give welfares to Chinese firms in the period of 1996 to 2003 ( $\mathrm{Ng}$ et al., 2009). However, sometimes when there is a mixed control in a firm, this would lead to poor performance due to ambiguity of ownership control, property rights, agency problems, profits and welfare objectives. Moreover, the result also shows negative relation between government ownership and performance (Zakaria and Purhanudin, 2014).

Government ownership may impact on a firm's performance if there is misalignment of the goals of the government with other shareowners. The goal of ordinary shareholders is to maximize wealth.Government ownership, however, may have different goals - social (i.e. to increase employment) or political (i.e. to prevent penetration by foreign investors and protect domestic producers). The adverse impact of government ownership on firm performance is because government ownership has different goals to those of other owners (Capobianco and Christiansen, 2011). It is also argued that government ownership suffers from high agency cost, often from poor corporate governance, and thus, that government ownership has a negative effect on firm performance (Shleifer, 1998). An investi- 
gation into the effect of ownership structure on firm performance finds that government ownership has a negative impact on firm performance (Thomsen and Pedersen's, 2000). Another study used a sample of 1034 listed firms in China from 2000 to 2004 and showed a negative influence of government ownership on firm performance (Gunasekarage et al., 2007). Some studies found non-linear effects of government ownership on firm performance. A study pointed out a U-shaped relationship between government ownership and firm performance in Chinese privatised firms in 1994, 1995, and 1996. Another study investigated Chinese privatized companies over the period 1996-2003 and found a convex connection between government ownership and firm performance. This implies that firms with substantial government ownership benefit from the support of the government or political connections. (Mishra and Phung, 2015; Hess et al., 2010; Ng et al., 2009).

\section{According to the preceding discussi-} on, the third hypothesis is as follows:

H3:There is a relationship between government ownership and firm performance.

\section{Measures of firm performance}

The financial performance of a firm can be measured in terms of profitability, dividend growth, sales turnover, asset base, capital employed among others (Almajali et al., 2012). However, there is still several debates concerning how the performance of firms could be measured and the factors that would affect the performance of firms (Liargovas and Skandalis, 2008). Using one factor would not reflect every side of a firm performance and therefore it is better to use several factors in order to allow a better evaluation of the financial performance of firms (Elvin and Abdul Hamid, 2016).

Of the useful financial performance indicators used in literature, ROA and return on equity (ROE) (Zouari and Taktak, 2014). ROA has been used by many studies to measure for firm performance (Demsetz and Villalonga, 2001; Douma et al., 2006; Phung and Le, 2013). Tobin's Q was used as a market performance measure in many studies. It was found that ownership does not predict performance, but performance negatively predicts ownership when using this measure (Loderer and Martin, 1997). Since Q ratios measure growth opportunities already capitalized in the stock price, managers are incentivized to liquidate their own firm stock ownership and diversify their wealth. It was also found that firm performance had effect on ownership structure, but not vice versa (Cho, 1998). Thus ownership may not be an effective incentive mechanism to induce managers to make value maximizing investment decisions (Haldar and Rao, 2011).

\section{Methodology of the Study Sample and variables}

The study uses ownership and financial data of the companies listed on the Egyptian stock market for thirteen years (2003: 2015). The study depends mainly on primary data of 50 firms. The samples were identified according to the firm rank in the market, the top 50 firms were chosen for the current study.

The data comes from the annual reports of these companies ranging from 2003 to 2015. 
As mentioned above, the main objective is to present empirical evidence of the relationship between ownership structure and business performance.To achieve this, the model proposes an estimation that uses different measures of performance as dependent variables and ownership structure as the main explanatory variable. We also include a group of control variables.

Three ownership structure variables are used in the study. As a proxy for ownership concentration, Block holder as measured by the percentage of shares held by large external shareholders (greater than 5\%). While managerial ownership is measured by the percentage of shares held by board members, government ownership is measured by the percentage of shares held by government investors (Varela, 2003; Wei et al., 2005; Ng et al., 2009; Taufil-Mohd et al., 2013; Zhang and Kyaw, 2017; Kaserer and Moldenhauer, 2008).

Three variables are selected as a measure for firm performance: various accounting measures are used in previous studies such as Return on equity (ROE) and Return on assets (ROA).The ROE measures the return on the investment of the owners; and ROA measures the return of both equity holders and debt holders.

A market based measure such as Tobin's $Q$ is a popular proxy for firm performance in empirical studies of corporate governance because maximizing firm value is regarded as the objective of the firm. Several control variables are introduced: firm size, leverage and firm age (Zouari and Taktak, 2014; Demsetz and Villalonga, 2001; Douma et al., 2006; Phung and Le, 2013; Loderer and Martin, 1997).
Firm Size: the variable is defined as the logarithm of total assets. Literature from previous studies has shown the importance of firm size in influencing the performance.The larger firm brings economies of scale and has more capabilities. However, the larger size may also decrease firm's growth, because of the decreasing marginal benefit of the scale. (Chae et al., 2009).

Financial Leverage: the variable is defined as total debts divided by the net equity and it measures the effect of financial leverage on firm performance. Firm leverage has a positive impact on firm performance. Some studies indicate a positive relationship, while others reveal a negative or a non-linear relationship (Margaritis \& Psillaki, 2010). An increase in firm leverage can mitigate agency problems and help improve firm performance. While Davies et al. (2005) showed a positive effect of leverage on firm performance, there are studies showing a negative effect of firm leverage on firm performance (Demsetz \& Villalonga, 2001; Andres, 2008; Gurbuz \& Aybars, 2010).

Firm Age: the variable is defined as the logarithm of the number of years between the observation year and firm founding year. This variable shows the life cycle effects.

While most of the studies show negative relationship between firm age and performance (Anderson \& Reeb 2003, Han \& Suk 1998), some studies show the opposite result. Firm age indicates how long a firm has existed in the market. Firms with a long history accumulate experience and this may help them 
increase performance (Gurbuz \& Aybars, 2010).

The data collected were analyzed by using the Statistical Package for Social
Sciences (SPSS) software. The generic specification of the model used in the estimates is the following.

$$
\begin{gathered}
\text { ROE }=\beta_{0}+\beta_{1} M O+\beta_{2} G O+\beta_{3} B H+\beta_{4} \text { Siz }+\beta_{5} \text { Lev }+\beta_{6} \text { Age } \\
\text { ROA }=\beta_{0}+\beta_{1} M O+\beta_{2} G O+\beta_{3} B H+\beta_{4} \text { Siz }+\beta_{5} \text { Lev }+\beta_{6} \text { Age } \\
Q \text { Ratio }=\beta_{0}+\beta_{1} M O+\beta_{2} G O+\beta_{3} B H+\beta_{4} \text { Siz }+\beta_{5} \text { Lev }+\beta_{6} \text { Age }
\end{gathered}
$$

Where; $\beta 0=$ constant term; $\mathrm{ROE}=$ Return on equity; ROA = Return on Assets; Q Ratio= Tobin's Q; MO = Managerial Ownership; GO = Government Ownership; BH = Block Holders Ownership; Si z= Firm Size; LEV = Leverage; and Age $=$ Firm Age.

\section{Data Analysis and Findings}

\section{Descriptive Analysis}

Table 1 shows the descriptive analysis to describe the basic features of the data in the study. They provide simple summaries about the sample and the measures. The quantitative data are measured using measures of central tendency and dispersion as shown in the table below. It can be observed that the average ROE is $14,09 \%$ and standard deviation of $34,622 \%$. In addition, the average ROA is $6,33 \%$, with standard deviation of $10,923 \%$. In addition, the average $Q$ ratio is 1.4230 with standard deviation of 1.38512 .

This table also including the minimum, maximum, mean, variance and standard deviation for all variables under study.

\section{Table 1 Descriptive Analysis of the Research Variables}

\begin{tabular}{lcccccc}
\hline & N & $\begin{array}{c}\text { Mini- } \\
\text { mum }\end{array}$ & $\begin{array}{c}\text { Maxi- } \\
\text { mum }\end{array}$ & Mean & $\begin{array}{c}\text { Std. } \\
\text { Deviation }\end{array}$ & Variance \\
\cline { 2 - 7 } Managerial Ownership & 650 & .00 & .64 & .0667 & .12289 & .015 \\
Government Ownership & 650 & .00 & .49 & .0276 & .06501 & .004 \\
Block Holders more than 5\% & 649 & .00 & 1.00 & .5149 & .28440 & .081 \\
Size & 650 & 3.99 & 7.98 & 5.9464 & .74787 & .559 \\
Leverage & 650 & -3.85 & 23.71 & .7000 & 1.81248 & 3.285 \\
Age & 650 & .60 & 2.21 & 1.4450 & .32644 & .107 \\
ROE & 641 & -4.38 & 5.55 & .1409 & .34622 & .120 \\
ROA & 641 & -.57 & .40 & .0633 & .10923 & .012 \\
Q ratio & 650 & .08 & 17.46 & 1.4230 & 1.38512 & 1.919 \\
\hline
\end{tabular}




\section{Hypotheses Testing}

\section{Relationship between Owner-} ship Structure, Control Varia-

\section{bles and ROE}

Table 2 shows the correlation matrix between independent variables of Ownership structure; Managerial Ownership, Government Ownership, and Block Holder, Control variables, including Size, Leverage and Age, and the financial performance indicator; ROE. It was observed that the value of Pearson's correlation for the research variables; Managerial Ownership, government Ownership, Block Holders, Size, Leverage, and Age are $-0.001,-0.082,0.191,0.123$, $-0.340,-0.024$ respectively, with $\mathrm{P}$ values of $0.972,0.037,0.000,0.002$, 0.000 , and 0.539 . Thus, there is a significant positive correlation between ROE and the research variables; Block Holders and Size, as corresponding Pvalues are less than 0.05 and $r>0$. In addition, there is a significant negative relationship between ROE and Government Ownership and Leverage, as corresponding $\mathrm{P}$-values are less than 0.05 and $r<0$. On the other hand, there is an insignificant relationship between ROE and Managerial Ownership and Age, as corresponding $\mathrm{P}$-values are greater than 0.05 .

Table 2 Correlation Matrix between ROE and Research Variables

\begin{tabular}{|c|c|c|c|c|c|c|c|c|}
\hline & & $\begin{array}{c}\text { Manageri- } \\
\text { al Owner- } \\
\text { ship }\end{array}$ & $\begin{array}{l}\text { Govern- } \\
\text { ment Own- } \\
\text { ership }\end{array}$ & $\begin{array}{c}\text { Block } \\
\text { Holders }\end{array}$ & Size & $\begin{array}{l}\text { Lever- } \\
\text { age }\end{array}$ & Age & ROE \\
\hline \multirow{2}{*}{$\begin{array}{l}\text { Managerial } \\
\text { Ownership }\end{array}$} & $\mathrm{r}$ & 1 & & & & & & \\
\hline & $\begin{array}{c}\text { P-value } \\
n\end{array}$ & 650 & & & & & & \\
\hline \multirow{3}{*}{$\begin{array}{c}\text { Government } \\
\text { Ownership }\end{array}$} & $\mathrm{r}$ & $.100^{*}$ & 1 & & & & & \\
\hline & P-value & .011 & & & & & & \\
\hline & $\mathrm{n}$ & 650 & 650 & & & & & \\
\hline \multirow{3}{*}{$\begin{array}{l}\text { Block Hold- } \\
\text { ers }\end{array}$} & $\mathrm{r}$ & $-.561^{*}$ & $-.335^{* * 1}$ & 1 & & & & \\
\hline & $\mathrm{P}$-value & .000 & .000 & & & & & \\
\hline & $\mathrm{n}$ & 649 & 649 & 649 & & & & \\
\hline \multirow[t]{3}{*}{ Size } & $\mathrm{r}$ & $-.104^{* *}$ & $-.188^{* * *}$ & $.399^{* *}$ & 1 & & & \\
\hline & $\mathrm{P}$-value & .008 & .000 & .000 & & & & \\
\hline & $\mathrm{n}$ & 650 & 650 & 649 & 650 & & & \\
\hline \multirow[t]{3}{*}{ Leverage } & $\mathrm{r}$ & -.029 & -.045 & .021 & $.107^{\text {**\% }}$ & 1 & & \\
\hline & $\mathrm{P}$-value & .457 & .252 & .594 & .006 & & & \\
\hline & $\mathrm{n}$ & 650 & 650 & 649 & 650 & 650 & & \\
\hline \multirow[t]{3}{*}{ Age } & $r$ & -.019 & .004 & .039 & .052 & -.053 & 1 & \\
\hline & P-value & .636 & .910 & .321 & .189 & .178 & & \\
\hline & $\mathrm{n}$ & 650 & 650 & 649 & 650 & 650 & 650 & \\
\hline \multirow[t]{3}{*}{ ROE } & $\mathrm{r}$ & -.001 & $-.082^{*}$ & $.191^{* * \pi}$ & $.123^{* * *}$ & $-.340^{* * *}$ & -.024 & 1 \\
\hline & P-value & .972 & .037 & .000 & .002 & .000 & .539 & \\
\hline & $\mathrm{n}$ & 641 & 641 & 640 & 641 & 641 & 641 & 641 \\
\hline
\end{tabular}


Table 3 shows regression analysis of the impact of the Ownership Structure and the control variables; Size, Leverage and Age on ROE. It could be observed that there is a positive significant impact of Managerial Ownership and Block Holders on the dependent variable; ROE with coefficients of 0.378 and 0.285 respectively, as well as $\mathrm{P}$-values of 0.004 and 0.000 respectively. In ad- dition, there is a significant negative impact of Leverage on ROE with coefficient of -0.067 and P-value of 0.000 , which is less than 0.05 . Other variables are shown to have an insignificant impact on ROE, which are Government Ownership, Size and Age. Also, the R square is 0.176 which means that the model explains $17.6 \%$ of the variation in ROE.

Table3 Regression Analysis of Independent Variables on ROE

\begin{tabular}{lcccccccc}
\hline & $\begin{array}{c}\text { Unstandard- } \\
\text { ized Coeffi- } \\
\text { cients }\end{array}$ & $\begin{array}{c}\text { Standard- } \\
\text { ized Coeffi- } \\
\text { cients }\end{array}$ & T & $\begin{array}{c}\text { P- } \\
\text { value }\end{array}$ & VIF & $\begin{array}{c}\text { Overall } \\
\text { P-value }\end{array}$ & $\begin{array}{c}\text { R } \\
\text { Square }\end{array}$ \\
\cline { 2 - 5 } B & $\begin{array}{c}\text { Std. } \\
\text { Error }\end{array}$ & Beta & & & & & \\
\hline (Constant) & -.112 & .121 & & -.928 & .354 & & & \\
Managerial & .378 & .131 & .125 & 2.879 & .004 & 1.459 & & \\
Ownership & & & & & & & & \\
Government & -.106 & .205 & -.020 & -.518 & .605 & 1.145 & & \\
Ownership & & & & & & & & \\
Block Holders & .285 & .062 & .231 & 4.594 & .000 & 1.943 & & \\
Size & .036 & .019 & .075 & 1.834 & .067 & 1.295 & & \\
Leverage & -.067 & .007 & -.353 & -9.710 & .000 & 1.019 & & \\
Age & -.056 & .039 & -.053 & -1.457 & .146 & 1.009 & & \\
\hline
\end{tabular}

Therefore, the regression equation can be stated as follows:

$\mathrm{ROE}=-0.112+0.378 *$ Managerial Ownership $-0.106 *$ Government Ownership $+0.285^{*}$ Block Holders $+0.036^{*}$ Size $-0.067 *$ Leverage $-0.056^{*}$ Age

The results shown by regression analysis is consistent with what is obtainned from correlation analysis in the impact of Block Holders and Leverage.

On the other hand, Government Ownership turns to be insignificant in the presence of other variables. Furthe- rmore, Managerial Ownership is shown to have a significant positive impact on ROE.

\section{Relationship between Owner- ship Structure, Control Varia- bles and ROA}

Table 4 shows the correlation matrix between independent variables of Ownership structure; Managerial Ownership, Government Ownership, and Block Holders, Control variables, including Size, Leverage and Age, and the financial performance indicator; ROA. It was 
observed that there is a significant positive relationship between $\mathrm{ROA}$ and $\mathrm{Bl}$ ock Holders and Size, as the corresponding correlation coefficients are 0.227 and 0.227 and corresponding P-values are 0.000 and 0.000 respectively.

In addition, there is a significant negative relationship between ROA and Leverage and Age, as the corresponding correlation coefficients are -0.119 and 0.184 with P-values of 0.003 and 0.000 respectively. Other variables are shown to have an insignificant relationship with ROA, like Managerial Ownership and Government Ownership, as corresponding P-values are greater than 0.05.

\section{Table 4 Correlation Matrix between ROA and Research Variables}

\begin{tabular}{|c|c|c|c|c|c|c|c|c|}
\hline & & $\begin{array}{r}\text { Managerial } \\
\text { Ownership }\end{array}$ & $\begin{array}{c}\text { Government } \\
\text { Ownership }\end{array}$ & $\begin{array}{c}\text { Block } \\
\text { Holders }\end{array}$ & Size & Leverage & Age & ROA \\
\hline \multirow{3}{*}{$\begin{array}{r}\text { Managerial } \\
\text { Ownership }\end{array}$} & $\mathrm{R}$ & 1 & & & & & & \\
\hline & $\mathrm{P}$-value & & & & & & & \\
\hline & $\mathrm{N}$ & 650 & & & & & & \\
\hline \multirow{3}{*}{$\begin{array}{c}\text { Government } \\
\text { Ownership }\end{array}$} & $\overline{\mathrm{R}}$ & $.100^{*}$ & 1 & & & & & \\
\hline & $\mathrm{P}$-value & .011 & & & & & & \\
\hline & $\mathrm{N}$ & 650 & 650 & & & & & \\
\hline \multirow{3}{*}{ Block Holders } & $\mathrm{R}$ & $-.561^{* * *}$ & $-.335^{* * *}$ & 1 & & & & \\
\hline & $\mathrm{P}$-value & .000 & .000 & & & & & \\
\hline & $\mathrm{N}$ & 649 & 649 & 649 & & & & \\
\hline \multirow{3}{*}{ Size } & $\bar{R}$ & $-.104^{* * *}$ & $-.188^{* * *}$ & $.399^{* * *}$ & 1 & & & \\
\hline & $\mathrm{P}$-value & .008 & .000 & .000 & & & & \\
\hline & $\mathrm{N}$ & 650 & 650 & 649 & 650 & & & \\
\hline \multirow{3}{*}{ Leverage } & $\mathrm{R}$ & -.029 & -.045 & .021 & $.107^{* * *}$ & 1 & & \\
\hline & $\mathrm{P}$-value & .457 & .252 & .594 & .006 & & & \\
\hline & $\mathrm{N}$ & 650 & 650 & 649 & 650 & 650 & & \\
\hline \multirow[t]{3}{*}{ Age } & $\mathrm{R}$ & -.019 & .004 & .039 & .052 & -.053 & 1 & \\
\hline & $\mathrm{P}$-value & .636 & .910 & .321 & .189 & .178 & & \\
\hline & $\mathrm{N}$ & 650 & 650 & 649 & 650 & 650 & 650 & \\
\hline \multirow[t]{3}{*}{ ROA } & $\mathrm{R}$ & -.009 & -.073 & $.227^{* * 4}$ & $.227^{* * 1}$ & $-.119^{* * *}$ & $-.184^{\text {*n: }}$ & 1 \\
\hline & $\mathrm{P}$-value & .816 & .066 & .000 & .000 & .003 & .000 & \\
\hline & $\mathrm{N}$ & 641 & 641 & 640 & 641 & 641 & 641 & 641 \\
\hline
\end{tabular}

Table 5 shows regression analysis of the impact of the Ownership Structure and the control variables; Size, Leverage and Age on ROA It could be observed that there is a positive significant impact of Managerial Ownership, Block Holders and Size on the dependent variable; ROA with coefficients of $0.134,0.099$ and 0.024 respectively, as well as P-values of 0.000 . In addition, there is a significant negative impact of
Leverage and Age on ROA with coefficient of -0.009 and -0.068 respectively, as well as P-value of 0.000 , which is less than 0.05. On the other hand, it was observed that there is an insignificant impact of Government Ownership on ROA, as corresponding P-value is 0.571 ( $\mathrm{P}$-value $>0.05)$. Also, the $\mathrm{R}$ sq-uare is 0.146 which means that the model explains $14.6 \%$ of the variation in ROA. 
Table 5 Regression Analysis of Independent Variables on ROA

\begin{tabular}{|c|c|c|c|c|c|c|c|c|}
\hline & \multicolumn{2}{|c|}{$\begin{array}{l}\text { Unstandardized } \\
\text { Coefficients }\end{array}$} & \multirow{2}{*}{$\begin{array}{l}\text { Standard- } \\
\text { ized Coef- } \\
\text { ficients } \\
\text { Beta }\end{array}$} & \multirow{2}{*}{$\mathbf{T}$} & \multirow{2}{*}{$\begin{array}{c}\text { P- } \\
\text { val- } \\
\text { ue }\end{array}$} & \multirow{2}{*}{ VIF } & \multirow{2}{*}{$\begin{array}{l}\text { Overall } \\
\text { P-value }\end{array}$} & \multirow{2}{*}{$\begin{array}{c}\mathbf{R} \\
\text { Square }\end{array}$} \\
\hline & $\mathbf{B}$ & $\begin{array}{l}\text { Std. } \\
\text { Error }\end{array}$ & & & & & & \\
\hline (Constant) & -.036 & .039 & & -.936 & .350 & & & \\
\hline $\begin{array}{l}\text { Managerial } \\
\text { Ownership }\end{array}$ & .134 & .042 & .141 & 3.185 & .002 & 1.459 & & \\
\hline $\begin{array}{l}\text { Government } \\
\text { Ownership }\end{array}$ & .037 & .066 & .022 & .566 & .571 & 1.145 & $0 \Omega 0$ & 116 \\
\hline Block Holders & .099 & .020 & .254 & 4.962 & .000 & 1.943 & & \\
\hline Size & .024 & .006 & .161 & 3.863 & .000 & 1.295 & & \\
\hline Leverage & -.009 & .002 & -.148 & -3.984 & .000 & 1.019 & & \\
\hline Age & -.068 & .012 & -.203 & -5.506 & .000 & 1.009 & & \\
\hline
\end{tabular}

Therefore, the regression equation can be stated as follows:

$\mathrm{ROA}=-0.036+0.134 *$ Managerial Ownership $+0.037 *$ Government Ownership $+0.099 *$ Block Holders $+0.024 *$ Size $-0.009 *$ Leverage $-0.068 *$ Age

The results shown by regression analysis is almost consistent with what is obtained from correlation analysis except that Managerial Ownership becomes having a significant positive impact on ROA.

\section{Relationship between Own- ership Structure, Control Variables and Q-Ratio}

Table 6 shows the correlation matrix between independent variables of Ownership structure; Managerial Ownership, Government Ownership, and Block Holders, Control variables, including
Size, Leverage and Age, and the financial performance indicator; Q Ratio. It was observed that there is a significant positive relationship between ROA and Block Holders, as the corresponding correlation coefficient is 0.130 and $\mathrm{P}$-value is 0.001 . In addition, there is a significant negative relationship between QRatio and Managerial Ownership, Government Ownership and Size, as the corresponding correlation coefficients are $-0.0 .80,-0.081$ and -0.107 with $\mathrm{P}$ values of $0.042,0.040$ and 0.006 respectively. Other variables are shown to have an insignificant relationship with ROA, like Leverage and Age, as corresponding P-values are greater than 0.05. 


\section{Table 6 Correlation Matrix between Q Ratio and Research Variables}

\begin{tabular}{|c|c|c|c|c|c|c|c|c|}
\hline & & $\begin{array}{c}\text { Managerial } \\
\text { Ownership }\end{array}$ & $\begin{array}{c}\text { Govern- } \\
\text { ment } \\
\text { Ownership }\end{array}$ & Block Holders & Size & $\begin{array}{l}\text { Lev- } \\
\text { erage }\end{array}$ & Age & Q Ratio \\
\hline \multirow{2}{*}{$\begin{array}{r}\text { Managerial } \\
\text { Ownership }\end{array}$} & $\mathrm{r}$ & 1 & & & & & & \\
\hline & $\begin{array}{c}\text { P-value } \\
n\end{array}$ & 650 & & & & & & \\
\hline \multirow{3}{*}{$\begin{array}{l}\text { Government } \\
\text { Ownership }\end{array}$} & $r$ & $.100^{*}$ & 1 & & & & & \\
\hline & P-value & .011 & & & & & & \\
\hline & $\mathrm{n}$ & 650 & 650 & & & & & \\
\hline \multirow{3}{*}{$\begin{array}{c}\text { Block Hold- } \\
\text { ers }\end{array}$} & $\mathrm{r}$ & $-.561^{* * *}$ & $-.335^{* * *}$ & 1 & & & & \\
\hline & P-value & .000 & .000 & & & & & \\
\hline & $\mathrm{n}$ & 649 & 649 & 649 & & & & \\
\hline \multirow[t]{3}{*}{ Size } & $\mathrm{R}$ & $-.104^{* *}$ & $-.188^{* *}$ & $.399^{* * *}$ & 1 & & & \\
\hline & P-value & .008 & .000 & .000 & & & & \\
\hline & $\mathrm{N}$ & 650 & 650 & 649 & 650 & & & \\
\hline \multirow{3}{*}{ Leverage } & $\mathrm{R}$ & -.029 & -.045 & .021 & $.107^{* * *}$ & 1 & & \\
\hline & P-value & .457 & .252 & .594 & .006 & & & \\
\hline & $\mathrm{N}$ & 650 & 650 & 649 & 650 & 650 & & \\
\hline \multirow[t]{3}{*}{ Age } & $\mathrm{R}$ & -.019 & .004 & .039 & .052 & -.053 & 1 & \\
\hline & P-value & .636 & .910 & .321 & .189 & .178 & & \\
\hline & $\mathrm{N}$ & 650 & 650 & 649 & 650 & 650 & 650 & \\
\hline \multirow[t]{3}{*}{ Q Ratio } & $\mathrm{r}$ & $-.080^{*}$ & $-.081^{*}$ & $.130^{* * *}$ & $-.107^{* * *}$ & .000 & -.011 & 1 \\
\hline & P-value & .042 & .040 & .001 & .006 & .992 & .789 & \\
\hline & $\mathrm{N}$ & 650 & 650 & 649 & 650 & 650 & 650 & 650 \\
\hline
\end{tabular}

Table 7 shows regression analysis of impact of Size on Q Ratio with coeffithe impact of the Ownership Structure cient of -0.368 and P-value of 0.000, and the control variables; Size, Lever- which is less than 0.05 . Other variables age and Age on Q Ratio. It could be ob- are shown to have an insignificant imserved that there is a positive signifi- pact on Q Ratio, which are Managerial cant impact of Block Holders on the de- Ownership, Government Ownership, pendent variable; Q Ratio with coeffi- Leverage and Age. Also, the R square cient of 0.990 and $\mathrm{P}$-value of 0.000 . In is 0.051 which means that the model addition, there is a significant negative explains only $5.1 \%$ of the variation in $\mathrm{Q}$ Ratio. 


\section{Table 7 Regression Analysis of Independent Variables on Q Ratio}

\begin{tabular}{lcccccccc}
\hline & \multicolumn{2}{c}{$\begin{array}{c}\text { Unstandardized } \\
\text { Coefficients }\end{array}$} & $\begin{array}{c}\text { Standardized } \\
\text { Coefficients }\end{array}$ & T & $\begin{array}{c}\text { P- } \\
\text { value }\end{array}$ & VIF & $\begin{array}{c}\text { Overall } \\
\text { P-value }\end{array}$ & $\begin{array}{c}\text { R } \\
\text { Square }\end{array}$ \\
\cline { 2 - 4 } & $\mathbf{B}$ & $\begin{array}{c}\text { Std. } \\
\text { Error }\end{array}$ & Beta & & & & & \\
\hline $\begin{array}{l}\text { Constant) } \\
\text { Managerial }\end{array}$ & 3.109 & .492 & & 6.314 & .000 & & & \\
$\begin{array}{l}\text { Ownership } \\
\text { Government }\end{array}$ & .229 & .532 & .020 & .430 & .668 & 1.515 & & \\
$\begin{array}{l}\text { Ownership } \\
\text { Block Hold- }\end{array}$ & -1.061 & .875 & -.050 & -1.213 & .226 & 1.146 & & \\
ers & .990 & .260 & .204 & 3.807 & .000 & 1.934 & & \\
$\begin{array}{l}\text { Size } \\
\text { Leverage }\end{array}$ & -.368 & .079 & -.199 & -4.649 & .000 & 1.240 & & \\
Age & .012 & .030 & .015 & .393 & .694 & 1.019 & & \\
\hline
\end{tabular}

Therefore, the regression equation can be stated as follows:

$\mathrm{Q}$ Ratio $=3.109+0.229 *$ Managerial Ownership - 1.061*Government Ownership $+0.990 *$ Block Holders $-0.368 *$ Size $+0.012 *$ Leverage $-0.004 *$ Age

The results shown by regression analysis are almost consistent with what is obtained from correlation analysis except that Managerial Ownership and Government Ownership turns to have an insignificant impact on Q Ratio.

\section{Discussion and Conclusion}

In the current research, Ownership structure had been classified into Managerial Ownership, Government Ownership and Block Holders more than $5 \%$.The above findings imply several results that should be discussed according to different measurements of financial performance. Considering ROE as the first measurement of financial performance, it had been shown that both; Managerial Ownership and Block Hol- ders have a positive significant impact on ROE, while Government Ownership has an insignificant impact on ROE. Observing ROA as the second measurement of financial performance, it had been observed that Managerial Ownership and Block Holders have a positive significant impact on ROA, while Government Ownership has an insignificant impact on ROA. These results regarding ROA is consistent with that obtained for ROE, which means that the impact on ROE and ROA is the same.

Regarding Q Ratio as the third measurement of financial performance, it had been noticed that only Block Holders have a positive significant impact on Q Ratio, while Managerial Ownership and Government Ownership have an insignificant impact on Q Ratio. This means that Managerial Ownership turns to have an insignificant impact in case of Q Ratio in contrast with the impact of Managerial Ownership on both; ROE 
and ROA. Regarding Government Ownership, it remains insignificant and thus Government Ownership has an insignificant impact on all financial performance indicators; ROE, ROA and Q Ratio. This agrees with the findings of Hess et al., 2010). At the same time, it is against the findings of (Wei and Varela, 2003; Wei et al., 2005; $\mathrm{Ng}$ et al., 2009) who found a positive relationship between ownership structure and the firm performance and Capobianco and Christiansen (2011) who argued that there is a negative relationship between ownership structure and the financial performance. On the other hand, Block Holders remains showing positive significant impact on Q Ratio, which means that Block Holders have a positive significant impact on all financial performance indicators; ROE, ROA and Q Ratio.

Thus, Ownership Structure in general has a positive significant impact on Financial Performance. This positive impact is mainly represented in Block Holders which shows the positive impact on all forms of financial performance. These findings agree with the findings of Taufil-Mohd et al., 2013 but contradicts with the findings of $\mathrm{Fa}$ zlzadeh et al., 2011. Also, it is represented in Managerial Ownership, which shows a significant positive impact on ROE and ROA. This is similar to the results of the research performed by (Fazlzadeh et al., 2011; Adebiyi and Sunday, 2011).
Regarding the control variables; $\mathrm{Si}$ ze, Leverage and Age, it had been shown that they are varying in their impact according to the financial performance indicator considered. In other words, Leverage was shown to have a positive significant impact on ROE, while it shows a negative significant impact on ROA. In addition, Size was shown to have a positive significant impact on ROA, while it shows a negative significant impact on Q Ratio. Moreover, Age was shown to have a negative significant impact on ROA, while it has an insignificant impact on ROE and Q ratio.

\section{Limitations and Future Re- search}

There are several limitations for the study. First, the empirical study was conducted only in Egypt. Moreover, the size of sample was relatively limited to the listed company in the stock market. Thus, it is recommended to replicate the study in different countries to get an international sample. Also, it is recommended to do the same study on other companies rather than those listed in the stock market in order to be able to generalize the results.

Future research that tries to investigate the relationship between ownership with company performance can also include other control variables to the study such as industry effects, firm risk, board characteristics, and the capital intensity to ensure the robustness of the results. Other performance measures also can be used as a proxy for firm performance such as earning per share 
(EPS), return on sales (ROS), return on investments (ROI), profit margin (PM), and economic value added (EVA). Then, the results can be compared to this study.

\section{References}

1. Adebiyi, A \& Sunday, K. (2011). Owner structure and firm performance: evidence from Nigerian listed companies. Corporate Ownership \& Control, 8(4), 391-400.

2. Abdelsalam, O.,El-Masry, A. \& Elsegini, S. (2008).Board composition, ownership structure and dividend policies in an emerging market Further evidence from CASE 50. Managerial Finance, 34 (12), 953-964.

3. Andow, H., \& David, B. (2016). Ownership structure and the financial performance of listed conglomerate firms in Nigeria. 5th International conference on Business \& Economic Development (ICBED), 7(3), 231240.

4. Anderson, C. \& Reeb, M. (2003). Founding-Family Ownership and Firm Performance: Evidence from the S\&P 500", The Journal of Finance, 58(3), 1301-1327.

5. Andres, C. 2008, 'Large Shareholders and Firm Performance - An Empirical Examination of Founding family Ownership', Journal of Corporate Finance, 14(4), 431-445.

6. AlmajaliY., Alamro, A., Al-Soub, Z. (2012). Factors affecting the financial performance of Jordanian insurance companies listed at Amman stock exchange. Journal of Management Research, 4(2), 266-289.
7. Ballinger, A. and Marcel, J. (2010). "The use of an interim CEO during succession episodes and firm performance", Strategic Management Journal, 31(3), 262-283.

8. Capobianco, A., Christiansen, H. (2011). Competitive Neutrality and Government-Owned Enterprises: Challenges and Policy Options. $O E$ CD Corporate Governance Working Papers, No. 1.

9. Cho, H. (1998). Ownership structure, investment, and the corporate value: An empirical analysis. Journal of Financial Economics, 47(1), 103-121.

10.Chae, J., Kim, S., \& Lee, J. (2009). How corporate governance affects payout policy under agency problems and external financing constraints. Journal of Banking \& Finance, 33(11), 2093-2101.

11.Demsetz, H. and Villalonga, B. (2001). Ownership structure and corporate performance. Journal of Corporate Finance, 7(3), 209-233.

12.Douma, S., George, R. \& Kabir, R. (2006). Foreign and Domestic Ownership, Business Groups, and Firm Performance: Evidence from a Large Emerging Market. Strategic Management Journal, 27(7), 637-57.

13.Elvin, P. Abdul Hamid, N. (2016). Ownership Structure, Corporate Governance and Firm Performance. International Journal of Economics and Financial Issues 6 (S3) 99-108.

14.Fazlzadeh, A., Hendi, A. \& Mahboubi, K.(2011).The Examination of the Effect of Ownership Structure on Firm Performance in Listed Firms of 
Tehran Stock Exchange Based on the Type of the Industry. International Journal of Business and Management, 6(3), 249-266.

15.Goyal, K. and Park, W.(2002).Board leadership structure and CEO turnover", Journal of Corporate Finance, 8 (1), 49-66.

16.Gunasekarage, A., Hess, K. and Hu, A. (2007). The Influence of the Degree of Government Ownership and the Ownership Concentration on the Performance of Listed Chinese Companies', Research in International Business and Finance, 21(3), 379395.

17.Gurbuz, A.O. and Aybars, A. 2010, 'The Impact of Foreign Ownership on Firm Performance, Evidence from an Emerging Market: Turkey', American Journal of Economics and Business Administration,2(4), 350359.

18.Hasan, A., \& Butt, A. (2009). Impact of Ownership Structure and Corporate Governance on Capital Structure of Pakistani Listed Companies. International Journal of Business and Management, 4(2), 50-57.

19.Han, C. \& Suk, Y. (1998). The Effect of Ownership Structure on Firm Performance: Additional Evidence, Review of Financial Economics, 7(2), 143-155.

20.Hansmann, H., \& Kraakman, H. (2004). Agency Problems and Legal Strategies. In: R. Kraalman, P. Davies, H. Hansmann, G. Hertig, K. Hopt, H. Kanda and E. Rock (Eds). The Anatomy of Coporate Law: A Comparative and Functional Appr- oach. Oxford University Press, Oxford. 21-31.

21.Hart, O. (1995). Corporate Governance: Some Theory and Implications, The Economic Journal, 105 (430), 678-89.

22.Haldar, A. \& Rao, S. (2011). Empirical study on ownership structure and firm performance. Indian Journal of Corporate Governance, 4 (2), 27-34

23.Hess, K., Gunasekarage, A. \& Hovey, M. (2010). Government-dominant and Non-government-dominant Ownership Concentration and Firm Performance: Evidence from China. International Journal of Managerial Finance, 6(4), 264-289.

24.Kaserer, C., \& Moldenhauer, B. (2008). Insider Ownership and Corporate Performance: Evidence from Germany. Review of Managerial Science, 2(1), 1-35.

25.Lee, S. (2008). Ownership Structure and Financial Performance: Evidence from Panel Data of South Korea. University of Utah, Department of Economics, Working Paper No. 17.

26.Loderer, C. \& Martin, K. (1997). Executive stock ownership and performance tracking faint traces. Journal of Financial Economics, 45 (2), 223-255.

27.Liargovas, P., Skandalis, K. (2008). Factors Affecting Firm Competitiveness: The Case of Greek Industry. European institute Journal, 2 (2), 184-197. 
28.Mishra, A. and Phung, D. (2015). Ownership structure and firm performance: evidence from Vietnamese listed firms. Australian economic papers, 55 (1), 63-98.

29.Margaritis, D. and Psillaki, M. (2010).Capital Structure, Equity Ownership and Firm Performance, Journal of Banking and Finance, 34(3), 621-632.

30.Ng, A., Yuce, A. \& Chen, E. (2009). Determinants of government equity ownership, and its effect on value/performance: China's privatized firms. Pacific-Basin Finance Journal, 17 (4), 413-443.

31.Phung, N. \& Le, V. (2013). Foreign Ownership, Capital Structure and Firm Performance: Empirical Evidence from Vietnamese Listed Firms. The IUP Journal of Corporate Governance, 12(2), 40-58.

32.Shakir, R. (2008). Board size, executive director and property firm performance in Malaysia. Pacific Rim Property Research Journal, 14(1), 66-80.

33.Shleifer, A. (1998).Government versus Private Ownership. The Journal of Economic Perspectives, 12(4), 133-150.

34.Thomsen, S. \& Pedersen, T. (2000). Ownership Structure and Economic Performance in the Largest European Companies, Strategic Management Journal, 21(6), 689-705.

35.Taufil-Mohd,K., Md-Rus,R. Musallam,S. (2013).The Effect of Ownership Structure on Firm Performance in Malaysia. International Journal of Finance and Accounting, 2(2) 7581.
36.Wei, B. \& Varela, O. (2003). Government equity ownership and firm market performance: evidence from China's newly privatized firms. Global Finance Journal, 14(1), 6582.

37.Wei, B., Xie, X. \& Zhang, R. (2005). Ownership structure and firm value in China's privatized firms: 1991-2001. Journal of Financial and Quantitative Analysis, 40(1), 87-108.

38.Uadiale, M. (2010). The Impact of Board Structure on Corporate Financial Performance in Nigeria. International Journal of Business and Management, 5(10), 155-161.

39.Ugurlu, M. (2000). Agency Costs and corporate control devices in the Turkish manufacturing industry. Journal of Economic Studies, 27(6), 566-599.

40.Zakaria, Z. \& Purhanudin, N. (2014). Ownership structure and firm performance: evidence from Malaysian trading and services sector. $E$ uropean Journal of Business and Social Sciences, 3 (2), 32-43.

41.Zhang, H., Kyaw, K. (2017). Ownership Structure and Firm Performance: An Empirical Analysis of Chinese Companies. Applied Economics and Finance, 4(2), 57-64.

42. Zouari, S. \& Taktak, N. (2014). Ownership structure and financial performance in Islamic banks Does bank ownership matter? International Journal of Islamic and Middle Eastern Finance and Management, 7(2), 146-160. 